\title{
ANALISIS KETAHANAN PANGAN RUMAH TANGGA PETANI PADI DI DESA PAWINDAN KECAMATAN CIAMIS KABUPATEN
}

\author{
ANALYSIS OF RICE FARMERS HOUSEHOLD RESILENCE ANALYSIS IN \\ PAWINDAN VILLAGE, CIAMIS DISTRICT, CIAMIS REGENCY
}

\author{
MELA RAHMAWATI ${ }^{1 *}$, TRISNA INSAN NOOR ${ }^{2}$, MUHAMAD NURDIN YUSUF $^{1}$ \\ ${ }^{1}$ Fakultas Pertanian, Universitas Galuh \\ ${ }^{2}$ Fakultas Pertanian, Universitas Padjadjaran \\ *E-mail: melarahmaw5@gmail.com
}

\begin{abstract}
ABSTRAK
Indonesia saat ini menghadapi tantangan dalam meghadapi kebutuhan pangan. Pangan merupakan kebutuhan pokok penduduk yang ketersediaannya harus cukup serta berkelanjutan. Sektor pertanian diharapkan dapat memenuhi kebutuhan konsumsi maupun pendapatan rumah tangga petani.Penelitian dilaksanakan dengan tujuan untuk mengetahui: (1) Struktur Pendapatan rumah tangga petani di Desa Pawindan Kecamatan Ciamis Kabupaten Ciamis, (2) Struktur Pengeluaran rumah tangga petani di Desa Pawindan Kecamatan Ciamis Kabupaten Ciamis, (3) Ketahanan Pangan rumah tangga petani padi di Desa Pawindan Kecamatan Ciamis Kabupaten Ciamis.Penelitian ini menggunakan metode survey terhadap 37 orag petani padi sawah yang ditentukan secara acak sederhana. Hasil penelitian menunjukkan: (1) Total rata-rata pendapatan rumah tangga petani di Desa Pawindan Kecamatan Ciamis Kabupaten Ciamis sebesar Rp 3.228,000 dari total pendapatan tersebut pendapatan Petani sebagai kepala keluarga sebesar 75,95 persen yang terdiri dari pendapatan usahatani sebesar 13,93, non padi sebesar 0.41 persen dan non pertanian sebesar 61,01 persen, serta pendapatan anggota keluarga sebesar 24,05 persen yang terdiri dari pendapatan pertanian sebesar 7,22 persen dan non pertanian sebesar 16,80 dari total pendapatan rumah tangga petani. (2) Total rata-rata pengeluaran rumah tangga petani di Desa Pawindan Kecamatan Ciamis Kabupaten Ciamis sebesar Rp 2.958,500/Bulan. Dari pengeluaran tersebut dialokasikan untuk kebutuhan pangan sebesar $40 \%$ dan untuk kebutuhan nonpangan sebesar 60\% dari total pengeluaran rumah tangga. (3) Tingkat ketahanan pangan rumah tangga petani di Desa Pawindan Kecamatan Ciamis Kabupaten Ciamis dilihat dari indikator tingkat subsistensi pangan tergolong rendah, indikator aksesibilitas rumah tangga tergolong tinggi, dan indikator pangsa pengeluaran pangan tergolong rendah. Dengan demikian maka secara umum tingkat ketahanan pangan rumah tangga petani di Desa Pawindan Kecamatan Ciamis Kabupaten Ciamis tergolong Tinggi
\end{abstract}

Kata Kunci: Struktur Pendapatan, Struktur Pengeluaran, Ketahanan Pangan, Rumah Tangga Petani.

\section{ABSTRACT}

The research was carried out with the aim of knowing: (1) Structure of household income of farmers in Pawindan Village, Ciamis District, Ciamis Regency, (2) Structure of household expenditure of farmers in Pawindan Village, Ciamis District, Ciamis Regency, (3) Food Security of rice farmer households in the Village Pawindan, Ciamis District, Ciamis Regency. This research used a survey method. Sampling was carried out by simple random sampling with a sample of 37 lowland rice farmers. The results showed: (1) The total household income of farmers in Pawindan Village, Ciamis District, Ciamis Regency was Rp. 3.228,000 of the total income the farmer's income as the head of the family 75,95 percent consisting of farm income of 13,93, non-rice income of 0.41 percent and nonagricultural by 61,01 percent, and income of family members of 24.05 percent consisting of agricultural income of 7,22 percent and non-agricultural income. agriculture is 16,80percent of the total household income of farmers. (2) The average household expenditure of farmers in Pawindan Village, Ciamis District, Ciamis Regency is Rp. 2.958,500/ month. Of this expenditure is allocated for food needs by $40 \%$ and for nonfood needs amounting to 60\% of total household expenditure, (3) The level of household food security in Pawindan Village, Ciamis District, Ciamis Regency, seen from the 
indicator of the level of food subsistence is low, the power indicator household purchases are classified as high, and the indicator for the share of food expenditure is classified as high.

Keywords: Income Structure, Expenditure Structure, Food Security, Farmers Household

\section{PENDAHULUAN}

Indonesia saat ini merupakan negara dengan jumlah penduduk yang cukup besar yang saat ini menghadapi tantangan dalam memenuhi kebutuhan pangan penduduknya yang sangat kompleks. Hal itu menjadikan pangan sebagai isu sentral dalam kehidupan berbangsa dan bernegara, sehingga perkara ketahanan pangan seharusnya dijadikan prioritas. (Wicaksono, 2012).

Pangan merupakan kebutuhan pokok untuk hidup bagi setiap manusia yang ketersediannya harus cukup, baik dari jumlah dan mutu yang sehat serta aman secara berkelanjutan. Ketahanan pangan termasuk dalam suatu kondisi terpenuhinya pangan yang cukup bagi masyarakat dari segi kualitas maupun kuantitas. Dalam penelitian (Hanani, 2012) terdapat beberapa aspek yang dapat mempengaruhi terhadap ketahanan pangan, yaitu : Ketersediaan (food avaibility), Keamanan Pangan (food safety), Akses Pangan (food access), dan Kualitas Pangan (food quality). Keempat aspek tersebut mengindikasikan bahwa pangan harus tersedia dalam jumlah yang cukup dan tersedia setiap saat secara berkelanjutan.

Komoditas pangan pokok di Indonesia sebagian besar adalah dari padi. Laporan BPS (2019) menunjukkan bahwa produksi padi pada tingkat nasional periode Januari hingga September 2018 tercatat sebanyak 49,65 juta ton Gabah Kering Giling (GKG) dengan kecenderungan meningkat. Provinsi Jawa Barat berada pada urutan ke 3 di Indonesia sebagai daerah penghasil padi. Namun, dengan jumlah produksi serta ketersediaan pangan yang cukup besar tersebut belum tentu menjamin ketahanan pangan pada tingkat wilayah (regional) serta menjamin ketahanan pangan pada tingkat rumah tangga. Kecamatan Ciamis merupakan Kecamatan yang berada di Ibu Kota Kabupaten. Oleh sebab itu, Kecamatan Ciamis memiliki wilayah sektor pertanian terbagi di berbagai Desa dengan luas lahan panen berjumlah 1,901 hektar dengan komoditas utama sektor pertanian padi sawah (BPS, 2019). Desa Pawindan memiliki luas lahan panen pertanian sebesar 58,22 hektar yang menjadikan Desa Pawindan sebagai daerah yang memiliki luas lahan panen paling 
sempit di Kecamatan Ciamis (BPS, 2019). Kondisi tersebut menjadikan Desa Pawindan memiliki permasalahan dalam jumlah produksi padi yang dihasilkan. Luas lahan panen yang terbatas mempengaruhi terhadap jumlah produksi padi yang dihasilkan. Hal ini sejalan dalam penelitian Hayati (2018), bahwa luas panen memiliki pengaruh yang signifikan terhadap produksi padi. Umumnya petani di Desa Pawindan merupakan petani berlahan sempit, sehingga return yang diperoleh juga kecil yang pada akhirnya berdampak terhadap kehidupan rumah tangga petani. Hal ini menunjukan bahwa hasil produksi merupakan penentu pendapatan petani yang berpengaruh pada perilaku petani dalam mewujudkan ketahanan pangan rumah tangga. Namun demikian, dengan keterbatasan lahan yang dimiliki akan berbanding lurus dengan hasil panen yang diperoleh. Artinya, semakin sempit lahan pertanian maka semakin kecil pula hasil produksi yang diperoleh. Keadaan ini menjadikan petani senantiasa berjuang untuk mewujudkan ketahanan pangan keluarganya. Guna mencapai tujuan tersebut banyak petani mencari alternatif lain untuk menambah pendapatan yaitu dengan menjadi buruh tani atau buruh harian lepas disamping pekerjaan utama mereka sebagai
Berdasarkan uraian tersebut, maka penelitian ini bertujuan untuk mengetahui: (1) Struktur pendapatan rumah tangga petani padi di Desa Pawindan Kecamatan Ciamis Kabupaten Ciamis. (2) Struktur pengeluaran rumah tangga petani padi di Desa Pawindan Kecamatan Ciamis Kabupaten Ciamis. (3) Tingkat ketahanan pangan rumah tangga petani padi di Desa Pawindan Kecamatan Ciamis Kabupaten

\section{METODE PENELITIAN}

Penelitian dilaksanakan dengan menggunakan metode survai. Singarimbun (1995), mengungkapkan bahwa metode survai yaitu metode yang mengambil sampel dari populasi dan menggunakan kuesioner untuk alat pengumpulan data pokok. Populasi penelitian sebanyak 230 petani, dan menentukan sampel penelitian dengan menggunakan rumus Slovin dengan error margin 15\% sehingga ukuran sampel sebanyak 37 petani. Data yang digunakan adalah data primer yang diperoleh melalui hasil wawancara dengan petani dan data sekunder yang diperoleh dari instansi terkait juga berbagai literatur.

Variabel-variabel dalam penelitian ini adalah:

1. Rumah tangga petani padi adalah semua orang yang berada di dalam satu unit rumah tangga, baik berasal dari 
satu atau lebih keluarga yang sumber pendapatan utamanya berasal dari usaha tani padi Efisiensi teknis merujuk pada hubungan input dan output, bagaimana petani memilih kombinasi input yang digunakan melalui kemampuan manajerial petani.

2. Struktur Pendapatan rumah tangga adalah penyusun pendapatan yang menunjukan dari mana saja sumber pendapatan rumah tangga diperolehbaik dari kepala rumah tangga dan seluruh anggota keluarga, yang meliputi :

a. Pendapatan yang berasal usaha tani (on farm) adalah pendapatan yang diperoleh petani dari pengasilan utama nya yaitu usaha tani padi yang dinyatakan dalam satuan rupiah per kapita per bulan.

b. Pendapatan diluar usaha tani (off farm) adalah pendapatan yang diperoleh petani dari luar usaha tani padi tetapi masih di sektor pertanian yang dinyatakan dalam satuan rupiah per bulan.

c. Pendapatan luar sektor pertanian (non farm) adalah pendapatan yang diperoleh petani dari luar sektor pertanian yang dinyatakan dalam satuan rupiah per bulan
3. Struktur pengeluaran rumah tangga merupakan penyusun biaya yang dikeluarkan untuk konsumsi semua anggota rumah tangga, meliputi :

a. Pengeluaran pangan, adalah pengeluaran yang dikeluarkan untuk rumah tangga untuk kebutuhan pangan, seperti : karbohidrat, protein, sayur-sayuran, kacang-kacangan, buah-buahan, minyak dan lemak, bahan minuman, bumbu-bumbuan, tembakau dan sirihyang dinyatakan dalam satuan rupiah per bulan.

b. Pengeluaran non pangan, adalah pengeluaran yang dikeluarkan rumah tangga untuk kebutuhan diluar pangan,seperti : pendidikan, transfortasi, komunikasi, perlengkapan pribadi, kesehatan, perbaikan rumah, pajak dan pengeluaran lainnya (social, sumbangan, hajatan, dll) yang dinyatakan dalam satuan rupiah per bulan.

4. Ketahanan pangan diartikan sebagai terpenuhinya pangan dengan ketersediaan yang cukup, tersedia setiap saat disemua daerah, mudah memperoleh, aman dikonsumsi dan harga yang terjangkau, yang diukur melalui : 
a. Ketersediaan, adalah proporsi pangan pokok yang dihasilkan sendiri terhadap kebutuhan pangan pokok keluarga.

b. Akses Pangan, adalah kemudahan rumah tangga dalam memperoleh pangan yang diukur dengan daya beli terhadap pangan.

c. Kualitas pangan, adalah kondisi rumah tangga petani yang memiliki pengeluaran untuk pangan yang lebih beragam yang diukur oleh pangsa pengeluaran pangan rumah tangga.

5. Tingkat Ketahanan Pangan rumah tangga merupakan penjumlahan ketiga indikator ketahanan pangan yaitu ketersediaan pangan, aksesibilitas pangan, dan kualitas/keamanan pangan. Berdasarkan indikator tersebut, maka tingkat ketahanan pangan rumah tangga dikategorikan menjadi :Rendah, Sedang, dan Tinggi.

(1) Untuk mengetahui Struktur pendapatan rumah tangga petani padi sawah menggunakan rumus Manullang, dkk., 2017) :

$\mathbf{P r t}=\mathbf{P}$ on-farm padi $+\mathbf{P}$ off-farm $+\mathbf{P}$ nonfarm

Dimana :

Prt $=$ Pendapatan rumah tangga $(\mathrm{Rp} / \mathrm{bulan})$
$\mathrm{P}$ on-farm = Pendapatan utama rumah tangga dari hasil pertanian (Rp/bulan)

$\mathrm{P}$ off-farm = Pendapatan rumah tangga dari kegiatan sektor pertanian ( $\mathrm{Rp} / \mathrm{bulan})$

$\mathrm{P}$ non-farm $=$ Pendapatan rumah tangga dari sektor luar pertanian (Rp/bulan)

(2) Untuk mengukur total pengeluaran rumah tangga digunakan rumus sebagai berikut (Amaliyah, 2011):

$\mathrm{TP}=\mathrm{Pp}+\mathrm{Pn}$

Dimana :

$\mathrm{TP}=$ Total pengeluaran rumah tangga petani (Rp/bulan)

$\mathrm{Pp}=$ Pengeluaran pangan (Rp/bulan)

$\mathrm{Pn}=$ Pengeluaran non pangan (Rp/bulan)

\section{(3) Indikator Ketahanan Pangan}

\section{Rumah Tangga :}

\section{a. Indikator Ketersediaan Pangan Rumah Tangga Petani}

Dalam pengukuran ketersediaan pangan mengacu pada kondisi yang cukup dan tersedia dalam jumlah yang bisa mencukupi konsumsi pangan rumah tangga..

Ketersediaan pangan dihitung dengan menggunakan rumus sebagai berikut (Yusuf, dkk., 2018) :

$\mathrm{TSP}=\mathrm{PUB} / \mathrm{KSB}$

Dimana :

TSP : Tingkat Subsistensi Pangan

PUB : Produksi dari usahatani sendiri setara beras

KSB : Kebutuhan setara beras 
b. Indikator

\section{Aksesibilitas}

Keterjangkauan Rumah Tangga

Petani

Indikator keterjangkauan pangan pada tingkat rumah tangga petani dalam pengukuran ketahanan pangan pada tingkat rumah tangga diukur dari kemudahan suatu rumah tangga dalam memperoleh pangan yang diukur dengan daya beli. Daya beli petani terhadap pangan dihitung dengan menggunakan rumus sebagai berikut (Yusuf, dkk., 2018) :

$\mathrm{DBPP}=\mathrm{TP} /(\mathrm{TE}-\mathrm{BU})$

Dimana :

DBPP : Daya beli rumah tanga petani

TP : Total pendapatan rumah tangga petani (Rp/kapita/bulan) dari seluruh sumber

TE : Total pengeluaran rumah tangga petani ( $\mathrm{Rp} / \mathrm{kapita/bulan)}$

BU : Biaya usaha tani

\section{c. Indikator Kualitas Keamanan \\ Pangan Rumah Tangga Petani}

Kualitas/keamanan pangan dilihat dengan pangsa pengeluaran pangan, yang merupakan rasio pengeluaran untuk berbelanja pangan dan pengeluaran total rumah tangga dalam sebulan. Rumah tangga yang memiliki pangsa pegeluaran pangan yang tinggi mengindikasikan rumah tangga tersebut tingkat ketahanannya yang rendah, sebaliknya jika rumah tangga dengan pangsa pegeluaran yang rendah mengindikasikan rumah tangga tersebut memiliki ketahanan pangan yang tinggi.

Pangsa pengeluaran pangan dihitung menggunakan rumus sebagai berikut (Arifin dkk., 2010) :

PPP

$=\frac{\text { Pengeluaran Pangan Rumah Tangga }}{\text { Total Pengeluaran }}$

$\times 100 \%$

Dimana :

PPP : Pangsa pengeluaran untuk pangan (\%)

\section{HASIL DAN PEMBAHASAN}

Struktur Pendapatan Rumah Tanga Petani Padi

Struktur pendapatan merupakan penyusun pendapatan yang menunjukan dari mana saja sumber pendapatan rumah tangga diperoleh baik dari kepala rumah tangga dan seluruh anggota keluarga selama periode waktu tertentu. Dalam sumber pendapatan keluarga, anggota keluarga seperti istri, anak yang sudah dewasa ikut terlibat dalam mencari penghasilan. Seperti menjadi buruh tani, karyawan toko, berdagang, guru, perangkat desa, PNS, dan sebagainya. Sektor pertanian sudah sulit mendapatkan kesempatan kerja dan kecenderungan 
generasi muda untuk lebih memilih pekerjaan diluar sektor pertanian untuk menambah pendapatan

Struktur sumber pendapatan petani dan anggota keluarga dari sektor pertanian dan luar sektor pertanian dapat dilihat pada Tabel 1.

Tabel 1. Struktur Pendapatan rata-rata Petani (Kepala Keluarga) dan Anggota Keluarga Dari Sektor Pertanian dan Non Pertanian

\begin{tabular}{rlrr}
\hline No & Uraian Sumber Pendapatan & Nilai (Rp) & Presentase (\%) \\
\hline 1 & Petani (Kepala Keluarga) & & \\
& $-\quad$ Usahatani Padi & 449.243 & 13,93 \\
& $-\quad$ Non Padi & 13.378 & 0,41 \\
& $-\quad$ Non Pertanian & $1.988,919$ & 61,01 \\
& Total Pendapatan (Rp/Bulan) & $2.451,531$ & 75,95 \\
& & & \\
& Anggota Keluarga (Istri, anak0 & 233.333 & 7,22 \\
& - Pertanian & 542.973 & 16,80 \\
& $-\quad$ Non Pertanian & 776.306 & 24,05 \\
& Jumlah Pendapatan & $3.227,837$ & 100,00 \\
\hline
\end{tabular}

Sumber: $\quad$ Analisis Data Primer, 2020

\section{Struktur Pengeluaran Rumah Tangga}

\section{Petani Padi}

Struktur pengeluaran rumah tangga terdiri atas pengeluaran pangan dan pengeluaran non pangan, keduanya berhubungan erat dengan tingkat pendapatan, artinya semakin besar pendapatan bertendensi untuk meningkatkan pengeluaran pangan dan non pangan rumah tangga (Yusuf, 2018). Ratarata total pengeluaran pangan petani dapat dilihat pada Gambar 1.

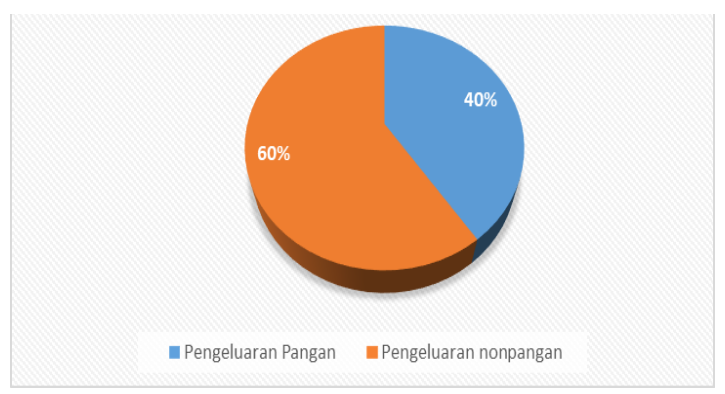

Gambar 1. menunjukan bahwa pengeluaran untuk kebutuhan non pangan lebih besar dibandingkan dengan pengeluaran untuk pangan yaitu sebesar $60 \%$ untuk pengeluaran nonpangan dan $40 \%$ untuk pengeluaran pangan. Hal tersebut menunjukan bahwa pendapatan petani sudah cukup tinggi. Petani dengan pendapatan yang cukup tinggi cenderung membelanjakan pendapatannya untuk 
kebutuhan non pangan. Dan sebagian pangan yang dikonsumsi oleh rumah tangga di Desa Pawindan Kecamatan Ciamis Kabupaten Ciamis yang terkesan seadanya yaitu memanfaatkan dari hasil produksi sendiri, sehingga pengeluaran pangan rumah tangga dapat ditekan dan pendapatannya dapat digunakan untuk memenuhi kebutuhan non pangan.

\section{Tingkat Ketahanan Pangan Rumah} Tangga Petani Padi

a. Indikator Ketersediaan Pangan Ruma Tangga

Kecukupan ketersediaan pangan rumah tangga dilihat dari ketersediaan pangan pokok (beras) yang dihasilkan sendiri terhadap kebutuhan pokok keluarga yang dihitung dengan cara membandingkan proporsi pangan pokok yang dihasilkan sendiri terhadap kebutuhan pangan pokok keluarga. (Yusuf, 2018). Sebaran rumah tangga berdasarkan kecukupan ketersediaan pangan dapat dilihat pada Tabel 2.

Tabel 2. Sebaran Rumah Tangga Berdasarkan Kecukupam Ketersediaan Pangan

\begin{tabular}{lcc}
\hline $\begin{array}{l}\text { Kecukupan } \\
\text { Ketersediaan }\end{array}$ & $\begin{array}{c}\text { Jumlah } \\
\text { (Orang) }\end{array}$ & $\begin{array}{c}\text { Persentase } \\
(\mathbf{\%})\end{array}$ \\
\hline Defisit (TSP $<1$ ) & 32 & 86,49 \\
Subsisten (TSP = 1) & 0 & 0 \\
Surplus (TSP > 1) & 5 & 13,51 \\
\hline \multicolumn{1}{c}{ Jumlah } & $\mathbf{3 7}$ & $\mathbf{1 0 0 , 0 0}$ \\
\hline
\end{tabular}

Sumber : Analisis Data Primer, 2020
Tabel 14 menunjukan bahwa dilihat dari kecukupan ketersediaan pangan dalam rumah tangga di dominasi mengalami defisit pangan yang ditunjukan oleh nilai TSP $<1$. Hal ini berarti bahwa petani tidak mampu mencukupi kebutuhan pangan rumah tangganya. Kurangnya ketersediaan pangan dalam rumah tangga menandakan bahwa tingkat ketahanan pangan rumah tangga tergolong rendah.

b. Indikator Aksesibiltas Rumah Tangga Terhadap Pangan

Aksesibilitas rumah tangga terhadap pangan dilihat dari kemudahan rumah tangga dalam mendapatkan pangan yang diukur melalui daya beli rumah tangga, semakin tinggi daya beli petani menjadikan tingkat ketahanan pangan menjadi lebih baik. (Yusuf, 2018). Sebaran rumah tangga berdasarkan aksesibilitas terhadap pangan dapat dilihat pada Tabel 3.

Tabel 3. Sebaran Rumah Tangga Berdasarkan Indikator Aksesibilitas Pangan

\begin{tabular}{lcc}
\hline $\begin{array}{c}\text { Tingkat Daya } \\
\text { Beli }\end{array}$ & $\begin{array}{c}\text { Jumlah } \\
(\text { Orang) }\end{array}$ & $\begin{array}{c}\text { Persentase } \\
(\mathbf{\%})\end{array}$ \\
\hline Rendah $(<1)$ & 15 & 40,55 \\
Sedang $(=1)$ & 2 & 5,40 \\
Tinggi $(>1)$ & 20 & 54,05 \\
\hline Jumlah & $\mathbf{3 7}$ & $\mathbf{1 0 0 , 0 0}$ \\
\hline Sumber : Analisis Data Primer, 2020 \\
Tabel 3. menunjukan bahwa berdasarkan \\
indikator daya beli, rumah tangga petani di \\
Desa Pawindan Kecamatan Ciamis
\end{tabular}


Kabupaten Ciamis di dominasi mempunyai daya beli yang tinggi (>1), Tingginya daya beli rumah tangga petani di Desa Pawindan Kecamatan Ciamis Kabupaten Ciamis disebabkan rata-rata petani mempunyai pekerjaan sampingan selain berusaha tani untuk memenuhi kebutuhan pengeluaran rumah tanga serta memiliki kemampuan untuk menyisihkan pendapatannya untuk ditabung, sehingga meskipun pendapatan yang diperoleh dari hasil usahatani kecil, petani masih mampu untuk membiayai usahataninya.

c. Indikator Kualitas Keamanan Pangan Rumah Tangga Petani

Kualitas pangan rumah tangga dalam penelitian ini dilihat dari pangsa pengeluaran untuk pangan, sebab pangsa pengeluaran pangan dapat dijakdikan sebagai salah satu ukuran tingkat ketahanan pangan. Sebaran rumah tangga berdasarkan kualitas keamanan pangan dapat dilihat pada Tabel 4.

Tabel 4. Sebaran Rumah Tangga Berdasarkan Indikator Kualitas Keamanan Pangan Rumah Tangga

\begin{tabular}{ccc}
\hline $\begin{array}{c}\text { Kategori } \\
\text { (Skor) }\end{array}$ & $\begin{array}{c}\text { Jumlah } \\
\text { (Orang) }\end{array}$ & $\begin{array}{c}\text { Persentase } \\
(\boldsymbol{\%})\end{array}$ \\
\hline Rendah & 31 & 83,80 \\
Sedang & 3 & 8,10 \\
Tinggi & 3 & 8,10 \\
\hline Jumlah & $\mathbf{3 7}$ & $\mathbf{1 0 0 , 0 0}$ \\
\hline
\end{tabular}

Sumber : Analisis Data Primer, 2020
Tabel 16 menunjukan bahwa dilihat dari pangsa pengeluaran pangan, rata-rata rumah tangga petani di Desa Pawindan Kecamatan Ciamis Kabupaten Ciamis berada pada kategori rendah yaitu sebesar 83,80 persen, artinya kualitas pangan yang dikonsumsi oleh keluarga petani sudah cukup beragam yang meliputi sumber Karbohidrat (beras), sayuran, serta sumber protein hewani (daging).

\section{d. Tingkat Ketahanan Pangan Rumah}

\section{Tangga Petani}

Dilihat dari indikator tingkat subsistensi pangan tergolong rendah yaitu sebesar 86,49 persen hal tersebut terjadi karena dominasi rumah tangga petani tidak mampu untuk mencukupi kebutuhan pangan keluarganya dari hasil produksi usahataninya sendiri, sehingga sebagian petani harus membeli beras untuk mencukupi kebutuhan pangan keluarganya, sebagian lagi petani ada yang menjual sebagian hasil produksi padi yang dihasilkan daripada menyimpan untuk cadangan pangan rumah tangga. Dilihat dari Indikator aksesibilitas rumah tangga yang diukur mealui daya beli tergolong tinggi yaitu sebesar 54,05 persen hal tersebut disebabkan dominasi petani di daerah penelitian mempunyai pekerjaan sampingan diluar sektor pertanian, sehingga meskipun pendapatan yang 
diterima petani dari hasil usahatani belum bisa mencukupi kebutuhan keluaarga, masih ada pendapatan lain diluar sektor pertanian yang dapat menambah pendapatan rumah tangga, sehingga petani dapat mencukupi pengeluaran rumah tangga dan membiayai usahatani untuk musim tanam berikutnya. Dan jika dilihat dari indikator pangsa pengeluaran pangan tergolong rendah yaitu sebesar 83,80 persen yang artinya kualitas pangan yang dikonsumsi oleh keluarga petani sudah cukup beragam, sehingga pendapatan yang diperoleh dapat tercukupi untuk kebutuhan pangan dan dapat dialokasikan untuk pemenuhan kebutuhan lain diluar pangan (sektor sekunder). Dengan demikian maka dapat disimpilkan bahwa secara umum ketahanan pangan rumah tangga petani di Desa Pawindan Kecamatan Ciamis kabupaten Ciamis tergolong tinggi. Hal tersebut dapat dilihat pada Gambar 6 .

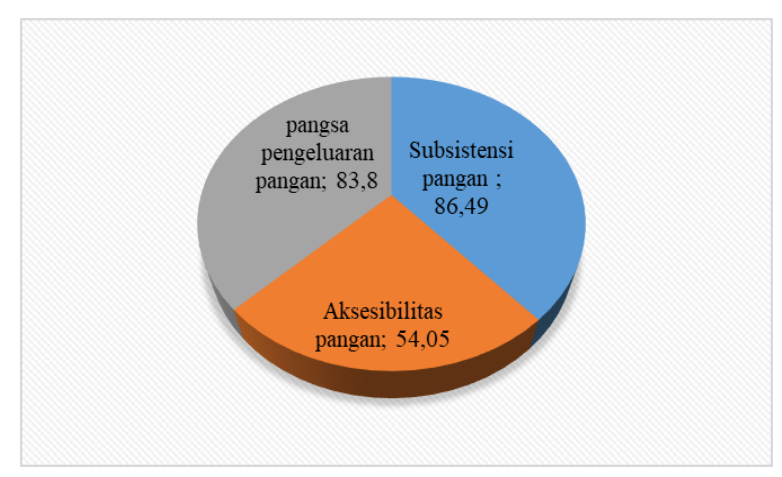

Sumber : Analisis Data Primer, 2020

\section{KESIMPULAN DAN SARAN}

\section{Kesimpulan}

Berdasarkan hasil dan pembahasan yang telah dilakukan dapat diambil kesimpulan sebagai berikut :

1. Total rata-rata pendapatan rumah tangga petani di Desa Pawindan Kecamatan Ciamis Kabupaten Ciamis sebesar Rp 3.228,000 dari total pendapatan tersebut pendapatan Petani sebagai kepala keluarga sebesar 75,95 persen yang terdiri dari pendapatan usahatani sebesar 13,93, non padi sebesar 0.41 persen dan non pertanian sebesar 61,01 persen, serta pendapatan anggota keluarga sebesar 24,05 persen yang terdiri dari pendapatan pertanian sebesar 7,22 persen dan non pertanian sebesar 16,80 dari total pendapatan rumah tangga petani.

2. Total rata-rata pengeluaran rumah tangga petani di Desa Pawindan Kecamatan Ciamis Kabupaten Ciamis sebesar Rp 2.958,500/Bulan. Dari pengeluaran tersebut dialokasikan untuk kebutuhan pangan sebesar $40 \%$ dan untuk kebutuhan nonpangan sebesar $60 \%$ dari total pengeluaran rumah tangga.

3. Tingkat ketahanan pangan rumah tangga petani di Desa Pawindan 
Kecamatan Ciamis Kabupaten Ciamis dilihat dari indikator tingkat subsistensi pangan tergolong rendah, indikator aksesibilitas rumah tangga tergolong tinggi, dan indikator pangsa pengeluaran pangan tergolong rendah. Dengan demikian maka secara umum tingkat ketahanan pangan rumah tangga petani di Desa Pawindan Kecamatan Ciamis Kabupaten Ciamis tergolong Tinggi.

\section{Saran}

Berdasarkan pada kesimpulan, maka dapat disarankan hal-hal sebagai berikut :

1. Petani diharapkan dapat mempertahankan lahan pertanian yang ada agar luas lahan tersebut tidak semakin menipis sehingga petani dapat meningkatkan jumlah produksi yang dihasilkan sehingga dapat menjadi sumber pendapatan.

2. Pemerintah daerah sebaiknya memberi dukungan pada rumah tangga petani dalam meningkatkan pendapatan dan pengetahuan tentang usahatani. Misalnya, dengan memberikan pelatihan dan penyuluhan keterampilan serta bantuan modal kepada rumah tangga petani padi.

3. Diperlukan penelitian lanjutan terkait distribusi pendapatan rumah tangga petani dan status gizi rumah tangga yang belum terungkap dalam penelitian ini.

\section{DAFTAR PUSTAKA}

Amaliyah, H., Handayani, M.S. 2011. Analisis Hubungan Proporsi Pengeluaran dan Konsumsi Pangan Dengan Ketahanan Pangan Rumah Tangga Petani Padi di Kabupaten Klaten. Jurnal SEPA, 7(2): 110-118.

Arifin., Suratiyah, K., Pinjung, N.S. 2010. Analisis Ketahanan Pangan Rumah Tangga Petani di Kabupaten Pinrang Sulawesi Selatan. Jurnal Sosial Ekonomi Pertanian. :137-143.

Badan Pusat Statistik Indonesia. 2018. Data Perkembangan Produksi Padi di Indonesia.

Badan Pusat Statistik Provinsi Jawa Barat. 2018. Data Jumlah Produksi Padi Sawah di Kabupaten Ciamis.

Hanani, N. 2012. Strategi Pencapaian Ketahanan Pangan Keluarga.Jurnal Sosial Ekonomi Pertanian.1(1): 1-9.

Hayati, N., Y. Pengaruh Tenaga Kerja Luas Panen dan Pupuk Terhadap Produksi Padi di Jawa Tengah. [Skripsi]. Universitas Muhammadiyah Surakarta. Jawa Tengah.Badan Pusat Statistik Indonesia. 2018. Luas Panen, Produksi dan Produktivitas Padi Sawah Provinsi Jawa Barat 20142018. Jakarta.

Manullang, E.N., Noor, I.T., Pardian, P., Syamsiah, N, 2017. Analisis Pendapatan dan Tingkat Kesejahteraan Rumah Tangga Petani Kedelai di Kecamatan Jatiwaras Kabupaten Tasikmalaya. Jurnal Ilmiah Mahasiswa Agroinfo Galuh, 4(3) : 464-471. 
Singarimbun, Masri. 1995. Metode Penelitian Survei. LP3S. Jakarta.

Wicaksono, Arditya. 2012. Optimalisasi Kepemimpinan Nasional dalam Melaksanakan Kebijakan Distribusi Pangan Dapat Mewujudkan Ketahanan Nasional. Jurnal Agriekonomika, 1(1): 36-46.
Yusuf, M.N, Sulistyowaty, L., Sendjaja, P.T, Carsono, N. 2018. Food Security Analysis of Household Paddy Farmer in Flooding Area. Journal Economics and Sustainable Development, 9(8): 88 